\title{
The Influence of Technology Readiness on Information Technology Competencies and Civil Conflict Environment
}

\author{
Haetham H. Kasem Alkhaffaf ${ }^{* 1}$, Kamil Md. Idris ${ }^{2}$, Akilah Abdullah² and Al-Hasan Al- \\ Aidaros $^{3}$ \\ ${ }^{1}$ Othman Yeop Abdullah Graduate School of Business, Universiti Utara Malaysia \\ 2 Tunku Puteri Intan Safinaz School of Accountancy, Universiti Utara Malaysia \\ 2 Islamic Business School, Universiti Utara Malaysia
}

\begin{abstract}
Nowadays, the employment of information technology (IT) in accounting is vastly exercised and has turned into an everyday routine, in which the accounting and financial operations can no longer be conducted efficiently without the use of IT. Therefore, accountants are increasingly utilising IT in a workplace to provide information to users efficiently. This study confirms prior findings that the Technology Readiness scale can capture the association among technology readiness and technology usage behaviours. This study also expands earlier research by investigating the impact of technology readiness on individual competency among accountants to using IT in a workplace under the intensity of civil conflict in Iraqi environment. The result showed that there is a positive significant relationship between technology readiness and the IT competencies of Iraqi accountants. It implies that the technology readiness regarding willingness, enthusiasm, and motivation of accountants using IT has an impact on their IT competencies. In other words, the higher the readiness of the accountants in making use of technology, the higher their competence in the use of IT. This study contributes to the body of knowledge in terms of theory, method and practice in Iraq especially and developing countries in general.
\end{abstract}

Keywords: Information Technology Competencies, Technology Readiness, Competency Theory, Technology Acceptance Model (TAM).

JEL Classification: 014

Paper Type: Research

*Corresponding author: E-mail: hh_haetham@yahoo.com 


\section{INTRODUCTION}

Information technology has made a significant advancement in every field of business domain especially in the field of accounting (Dimitrios, Sakas \& Vlachos, 2013). Among the first categories of professionals that this change has affected are accountants since integration, because IT has been integrated into their work on a daily basis (Kaye \& Nicholson, 1992; Rom \& Rodhe, 2007). Considering IT competency issues from a global perspective for every accountant, there is a need for the graduates of accounting to be equipped with applied IT skills and IT knowledge as required for employment (Lee \& Fang, 2008). IT has impacted positively on the processes of accounting.

The framework of competency for accountants is developed to ensure that there would be sufficient accountants who are competent and qualified to meet up with the industry's growing demands (Azmi, 2017). Both growth and change in the business environment have posed different challenges that the accountants need to meet. Such as IT is influencing the structure, function and administrative aspects of organizations, IT is affecting the competitive milieu in which professional accountants are working, IT is altering the economics and dynamics of accounting, and IT is opening up a variety of job opportunities for accountants in different fields such as design, evaluation, management and control of the system (IFAC, 2003). The challenges facing organisations require a particular kind of accountants who can understand how to use IT and when (and when not) to use it (Nance \& Straub, 1996). It is an essential issue in the competency area (IFAC, 2006a; Wessel, 2008).

Nowadays, Iraqi accountants are suffering from a weakness of IT competencies in workplace (Al-Dhahabi \& Jacob, 2014; Al-Fatlawi, 2013; Kaddouri, 2014) because these Iraqi accountants have suffered an extended period of internal crisis (i.e. civil conflicts) (ABC News, 2015; Al-Fatlawi, 2013), a weakness of educational qualification in the field of IT among Iraqi accounting graduates (Al-Busisi \& Al-Khafaji, 2009; Al-Jaboree, 2012; Lallo \& Selamat, 2013), the unstable environment and ongoing civil conflicts in Iraq led to undermining the socio-economic growth and deterioration of IT infrastructure (United Nations, 2014). The training in the field of IT has not been effectively among Iraqi accountants (Ministry of Industry \& Minerals, 2013), with a weakness of IT experience among Iraqi accountants (Al-Fatlawi, 2013). Thus, it is vital to study the IT competencies among accountants in the Iraqi organisations and to determine the factors that influence their IT competencies.

This issue is particularly important among Iraqi accountants as to improve IT competencies is claimed to be lagging behind those in developed and even some developing countries (Mohamed \& Lashine, 2003). Furthermore, the IT competencies among Iraqi accountants and Iraqi environment have many differences with those of the developed nations like the USA and Canada and even some developing countries like China, Turkey and Malaysia. Thus, results from those countries do not necessarily generalise to the Iraqi setting.

A report of Iraq Ministry of Industry and Minerals (MIM) (2013) indicated that the IT competencies among accountants in Iraqi organisations are still lagging behind those in developed countries and some of the developing countries. The accountants in industry firms suffered a shortage in the IT competencies of accountants because of the weakness of the IT skills, IT knowledge and level of training of them; as a result they do not have enough experience that qualifies them to deal with the problems faced by under the 
conditions of competition (MIM, 2013). A survey conducted by Central Statistical Organization in Iraq (CSO) (2013) on Manufacturing Industries Establishments and Ministries Headquarters reveals that $7.5 \%$ of accountants use a computer in the public sector. This ratio is very poor compared with other sectors that recorded $15.3 \%$.

According to the statistics of the e-auditing department on the Board of Supreme Audit of Iraq (BSA) (2014), it the state of IT competencies among Iraqi accountants needs more developments. This is due to many reasons such as economic, political, legal, educational, and technophobia factors that affect the accounting environment and its effect on the competencies of accountants. Also, the accreditation on the traditional manual systems to record events and financial operations and has neglected the use of software programs in accounting workplace because of the fear of using the computer and the belief that it is not safe (discomfort and insecurity).

The readiness of an IT user in embracing IT plays a vital role in the acquisition or realisation of IT competencies. Technological readiness (TR) is the willingness and enthusiasm of an IT user in the application of IT in the actualisation of a task (Parasuraman, 2000). Based on the literature, the relationship between technology readiness and IT competencies among professional accountants under the intensity of civil conflicts such as the Iraqi environment did not have been investigated before. A thorough review of the literature reveals that there is a paucity of research that has investigated the factors influencing the IT competencies in civil conflicts environments like Iraq. Therefore, the authors are interested to investigate this relationship in the current study. In addition, conflicting results were observed in previous studies between positive and negative, so, the current study is trying to verify this relationship. While the leading focal point on TR has been the technology-based services, Liljander, Gillberg, Gummerus, and Van Riel (2006) call for a rigorous study to explore the ability of TR in influencing users' IT competency and acceptance of the technology. This would be more relevant if TR is integrated with IT competencies among accountants in the framework. This study focuses on the association between TR and IT competencies among accountants in Iraq.

\section{LITERATURE REVIEW}

\subsection{The Concept of Information Technology Competencies (ITC)}

The term "IT competencies" represents a collection of IT knowledge and IT skills that allow an employee to act effectively in his/her work within various situations. The knowledge is defined as "what one knows" while skill is defined as "what one can do" (Stone, Arunachalam \& Chandler, 1996). The importance of distinguishing between these two terms and especially between the accounting related knowledge and skills has been acknowledged by various accounting academics and organisations (Deppe, Sonderegger, Stice, Clark, \& Streuling, 1991; Stone et al., 1996).On the other hand, Gold, Malhotra \& Segars (2001) define IT competencies as the shared IT capability that enables the flow of knowledge in organisations. Perry (1990) said IT competencies consist of three critical components, namely: IT knowledge, IT skills, and attitudes towards IT.

Bassellier, Benbasat, and Reich (2003) define IT competencies as the set of IT-related knowledge and experience that a business manager knowledge worker possesses. The authors propose two dimensions; IT knowledge and IT experience. According to Bahador and Haider (2012), IT competencies consist of four dimensions, i.e. those are technical skills, organisational skills, people skills and conceptual skills. 
According to IFAC (2003), the professional accountants must possess the necessary IT competencies because the credibility of the accountancy profession depends on their success in fulfilling this obligation. Thus, every professional accountant is expected to act as a user, designer, manager, planner or evaluator of information systems; or a combination of these roles (Wessel, 2008). It has to be recognised that these roles required technical skills, organisation skills, interpersonal skills, and other social skills. In the contemporary context, interpersonal skills are fundamental as these skills are necessary components of the skill required to support the professional accountants (IFAC 2003). IFAC identifies two types of IT knowledge, i.e. the conceptual IT knowledge and the practical IT skills. When it refers to IT competencies, it should be clear that competencies concern these two basic categories (IFAC 2003).

For Pérez-López and Junquera (2013), IT competencies deal with the ways that firms utilise technologies to manage the information efficiently and adequately. IT is a term that stands for computer, telecommunications or programs, whereas IT competency refers to using these tools to address the information needs of the firms (Mithas, Ramasubbu, \& Sambamurthy, 2011). Tippins and Sohi (2003) differentiate between IT knowledge, IT operations, and IT infrastructure. Each aspect of IT is a resource that shows to what extent the organisation can understand about the tools and use them effectively to deal with the information about markets and customers.

Looking at the definitions of IT competencies above, one can see all definitions include knowledge, skills, capabilities and attitudes. These aspects determine the level of performance in a specific work context. Fostering competencies can be beneficial to both the organisation and employees in different ways. For example, they can a) help employees to achieve the satisfactory results, b) predict a range of behaviours, c) guarantee the organisation's success if they are in line with business objectives. That is why organisations need to foster IT competencies, IT skills, IT knowledge and abilities of those who hold key positions. However, it is important to keep in mind that the environment (e.g., market, vendors, competitors, and governments) in which the organisation is working can negatively or positively influence the organisation activities.

As a summary, in this study, the term individual IT competencies refer to a person's ability to use personalized IT competencies within the workplace, contents a set of IT knowledge, IT skills (knowing how), and attitudes which decide the performance level of the context of a particular work (job, a group of jobs or function). These competencies help workers to fulfil results and hence create value.

\subsection{Technology Readiness}

The readiness of an IT user in embracing IT plays an essential role in the acquisition or realisation of IT competencies. The level to which individuals desire to use new technology is commonly determined by such factors as culture (Erumban \& de Jong, 2006; Singh, 2006), competency toward specific technologies (Bobbitt \& Dabholkar, 2001; Curran \& Meuter, 2005), the extent of technology anxiety showed by individuals (Meuter, Ostrom, Bitner, \& Roundtree, 2003), and an individual's ability and motivation to use (Walker, Lees, Hecker \& Francis, 2002). Studies have also revealed that individuals who are ready to use technology are more likely to try it (Parasuraman, 2000).

Technological readiness is the willingness and enthusiasm of an IT user in the application of IT in the actualisation of a task (Parasuraman, 2000). Davis (1989) came up with a 
model called TAM that is capable of recognising possible determinants and inhibitors of technology acceptance. In another development, a TR was proposed by Parasuraman (2000) to assess the propensity to grip and apply new technologies for the attainment of objectives at work and home life. In the study by Lin, Shih, and Sher (2007), TR was integrated into the TAM about consumer adoption of e-service systems and theorises that the effect of TR on use intention is wholly mediated by both perceptions of usefulness and ease of use. Originally, TAM was developed to predict the technology-adopting behaviour of people in work environments. TR was developed by Parasuraman (2000) to assess the extent to which people are willing to accept and apply the latest technologies. This index contains four concepts (optimism, innovativeness, discomfort and insecurity).

These four constructs measure an individual's general belief (i.e. readiness) towards new technology. The optimism dimension refers to a positive perception of technology and the notion that technology is advantageous in improving the efficiency of job and enhancing the lives of people both at work and at home. The second concept, which is innovativeness, refers to the extent to which an individual holds the notion that he or she is a thought leader, and at the vanguard of trying out new technology-based products/services. Thirdly, discomfort is the perceived lack of control over technology and a feeling of lack of confidence in applying the new technologies appropriately. Lastly, insecurity refers to distrust of technology-based transactions and scepticism about their ability to work properly. Though there appears to be a link between insecurity and discomfort dimension; it is argued by Parasuraman and Colby (2001) that this facet is different from discomfort, because it concentrates on particular aspects of technologybased transactions rather than on a lack of comfort with technology in general. The first two dimensions of technology readiness, "optimism" and "innovativeness" constitute the "contributors" that are capable of improving TR of individual, while the remaining two dimensions; "discomfort" and "insecurity" constitute the "inhibitors" that can suppress TR (Parasuraman \& Colby, 2001; 2015). These four elements can affect people's IT competencies (Lai, 2008).

\subsection{Research Framework}

The conceptualised system is based on competency of vocational education and training ideologies (Garavan \& McGuire, 2001; Hager \& Beckett, 1995) context of workplace learning (Jamil, 2015). The essential thrust relies on Kruger and Dunning (1999) competency theory (CT) which supports epistemological and psychological objectives. This standard is universal in competency frameworks developed in the disciplines of human resources, management education, accounting, and to a certain extent, psychological (e.g. Prahalad \& Hamel, 1990; Clardy, 2008; Boyatzis, 1982).

The literature has also presented some criticisms of competency theory (Carroll, Levy \& Richmond, 2008; Jamil, 2015). It is argued that the cognitive perception concepts undervalue such as personality traits which are significant to one's learning and development of individual competency such as technology readiness (optimism, innovativeness, discomfort \& insecurity). However, cognitive perspective ignored the intensity of civil conflicts and how the unique status could influence the IT competency (Jaeger \& Thompson, 2003; Khan, Moon, Zo, \& Rho, 2010, 2012). Thus far, making previous studies limited and incomprehensive.

The review of the literature found that research on acceptance of the information system has either focused on competencies in general and IT competencies in specific areas as 
adopted in the developed and developing nations. However, the literature review failed to find a model, which links Competency Theory (CT) and related theories such as Technology Acceptance Model (TAM) under the intensity of civil conflict in the same framework. In this study, CT as underpinning theory, it is adapted with TAM as a framework to investigate the IT competencies among Iraqi accountants under the intensity of civil conflicts.

On the other hand, TAM operates on individual performance. Davis (1989) asserted the extension and adding of external variables of original TAM of exploring the impacts of external factors on users' approach (competency) and actual use of technology such as IT Innovativeness, technology readiness, and computer anxiety (Abduljalil \& Zainuddin, 2015; Fathema, Shannon, Ross, 2015, Fathema, Ross, Witte, 2014). Previous studies documents usage of some parts of TAM instead of the holistic that is appropriate to the respondent under research (Maldonado, Khan, Moon \& Rho, 2011; Wang \& Yang, 2005). According to Greenstein-Prosch, McKee, and Quick (2008), the technology acceptance model (TAM), a user's perception of their computer knowledge (self-efficacy) increases their perceptions of ease of use of the technology and system usefulness, which in turn, can affect their behaviour and competency (Davis 1989). Therefore, this study examined technology readiness on IT competencies among public accountants in Iraq under the intensity of the civil conflict.

\subsection{Technology Readiness and IT Competency}

Some empirical research provides the insight that the TR scale can capture the association among technology readiness and technology usage behaviours (for example, Colby \& Albert, 2003; Farby, 2004; Parasuraman \& Colby, 2001). It is worthy to note here that Parasuraman and Colby (2001) stressed that technology readiness is an overall state of mind and not a determination of technical competency or ability. Some studies have come up with conflicting results concerning the TRI. Some indicate that TRI has a minor role in illustrating customer's behaviour towards technology (Liljander et al., 2006) and teachers' readiness (Summak, Bağlıbel, \& Samancıoğlu, 2010).

Other studies indicate that TRI has a vital role in identifying the users who intend to use technology before implementation (Caison, Bulman, Pai, \& Neville, 2008) and the extent to which the user is satisfied in using technology (Massey, Khatri, \& Montoya-Weiss, 2007). The TRI was first used to illustrate the readiness of customers towards technologybased services (e.g., financial and online services, telecommunications and electronic commerce). The findings showed that the TRI model is important in expecting the behaviour of the individual (Parasuraman, 2000). Then the model was adopted in other specific technologies on a vast scale such as mobile data services (Massey et al., 2007), airline check-in services (Liljander et al., 2006), self-service technologies (Elliot, Meng \& Hall, 2008), electronic healthcare records (Caison et al., 2008), social networking sites (Borrero, Yousafzai, Javed, \& Page, 2014), and ICT in education (Summak et al., 2010), among others.

In addition, previous studies did not investigate the relationship between technology readiness and IT competencies among professional accountants under the intensity of civil conflicts such as the Iraqi environment. Therefore, the researcher is interested in investigating this relationship in the current study. Also, conflicting results were observed in previous studies between positive and negative, so, the current study is trying to verify this relationship. While the leading focal point on TRI has been the technology-based 
services, Liljander, Gillberg, Gummerus, and Van Riel (2006) call for a rigorous study to explore the ability of TR in influencing users' IT competency and acceptance of the technology. This would be more relevant if TR is integrated with IT competencies among accountants in the framework. This study focuses on the association between TR and IT competencies among accountants in Iraq. Based on this, the following hypothesis is formulated for this construct:

H1: There is a positive relationship between technology readiness and IT competencies among Iraqi accountants.

\section{RESEARCH METHOD}

This research used the survey method with a quantitative approach. Data were collected from respondents who are working as accountants in the Iraqi public sector in different cities (Baghdad, Basra, Kirkuk and Erbil). A correlation test and regression analysis have used to analyse the data collection to explain the extent of the relationships among the research variables.

Data collection exercise, which was carried out by the researcher, ended with a reasonable response rate of 301 , out of 547 questionnaires distributed to the respondents. Out of the 301 returned questionnaires, 258 were usable while 43 were incomplete and removed. 258 usable surveys constitute an overall response rate of $47 \%$ which signifies an adequate response rate for the survey (Sekaran, 2003).

\subsection{Variables Measurement}

\subsubsection{IT Competency Scale}

The purpose of this section is to measure the information technology competencies among accountants. This section contained three dimensions. The first dimension is IT knowledge with a 12-items and its items were constructed based on several academic findings of many researchers (such as Coe, 2006; IFAC Guideline, 2006; Ismail \& Salim, 2005; Milus, 2004). The second dimension is IT skills with 13 items, and its items were constructed from several academic types of research (Bahador \& Haider, 2012; Bain, Blankley \& Smith, 2002; IFAC IEPS 2, 2007; Tam, 2011; Wessels, 2008) and the third dimension is attitudes towards IT with 6 items, based on the Loyd and Gressard's original format (1984). These scales are quite widely used for example (Berberoglu \& Calikoglu, 1993; Wallace, 1999). Responses are made on a 5-point scale ranging from 1 (strongly disagree) to 5 (strongly agree).

\subsubsection{Technology Readiness Scale}

Technology readiness was measured with a 9-item scale. The study adopted these items which were developed and validated by Parasuraman (2000) and Tsikritis (2004) studies. TR construct comprises four sub-dimensions: optimism, innovativeness, discomfort, and insecurity. Many researchers have used this scale and validated it in different contexts such as Lu, Wang and Hayes (2012); Victorino, Karniouchina and Verma (2009). Responses are made on a 5-point scale ranging from 1 (strongly disagree) to 5 (strongly agree). 


\section{ANALYSIS AND RESULTS}

This section focuses on data analysis and its outputs generated through SPSS version 23 as the following:

\subsection{Profile of Respondents}

In this section, the questionnaire provides the information about the respondent's specialisation, Work specification, Educational Level, Gender, age, Working experience Table 1 below summarises the results of respondents' profile.

Table 1. The results of the respondent profile section

\begin{tabular}{llcc}
\hline Demography & Indicators & Frequency & Percentage (\%) \\
\hline Work specification & Accountant & 111 & 43 \\
& Auditor & 147 & 57 \\
& Total & 258 & 100 \\
\hline Educational Level & Graduate & 132 & 51 \\
& Postgraduate & 126 & 49 \\
& Total & 258 & 100 \\
\hline Gender & Male & 194 & 75 \\
& Female & 64 & 25 \\
& Total & 258 & 100 \\
\hline Age & $20-29$ years & 43 & 17 \\
& $30-39$ years & 134 & 52 \\
& $40-49$ years & 55 & 21 \\
& $50-59$ years & 22 & 8 \\
& 60 years and above & 4 & 2 \\
& Total & 258 & 100 \\
\hline Working experience & Less than 1 year & 1 & 4 \\
& $2-5$ years & 71 & 28 \\
& $6-9$ years & 60 & 23 \\
& 10 years and above & 126 & 49 \\
\hline
\end{tabular}

Table 1 shows that the respondents are of diverse backgrounds, indicating that the data used in the study are from the respondents of diverse demographic backgrounds, and thus enriching generalizability of the result of the research.

\subsection{Reliability Test}

According to Tabachnick and Fidell (2007), reliability refers to the degree to which the items making up a given construct are error-free when measured many times. In the current study Cronbach's Alpha's value, which signifies the reliability of the constructs, firmness and stability of the items that constitute a given construct, is used. The value of Cronbach's Alpha is also employed to assess the goodness of a measure (Sekaran, 2003).

To determine the consistency of factors, reliability test using Cronbach's alpha value was conducted. The results in Table 2 below show that the Cronbach's alpha values were above the minimum accepted value of .6 as suggested by Nunnally (1978). This provided confidence to use those variables for subsequent analysis. 
Table 2. Reliability for Each Construct

\begin{tabular}{ll} 
Construct & Cronbach's Alpha \\
\hline IT Competencies & 0.927 \\
Technology Readiness & 0.749 \\
\hline
\end{tabular}

From Table 2, there is an indication that the Cronbach's alpha coefficients represent high and acceptable level and thus the constructs of the research are reliable. The Cronbach's alpha values for IT competencies, technology readiness are 0.927 and 0.749 respectively. Therefore, the result from Table 2 indicates robust scale and a good internal consistency of the constructs of the study. Given this, the constructs of the research are reliable and fit for further analysis. Given the previous analyses, next presents the result of the hypotheses testing.

\subsection{Correlation Test}

Pearson Product-Moment correlation is used in the current study to provide an initial understanding of the relationship and strength of the relationship between the independent variable and dependent variable (Pallant, 2011) and Sekaran (2000), as it is considered suitable for the analysis of connections among variables.

The correlation analysis in this section measured the intensity and direction of the linear relationship between technology readiness and IT competencies. The ranges of the correlation coefficient are ' -1 ' - ' +1 '. ' -1 ' indicates a negative relationship while ' 0 ' signifies no relationship, but ' +1 ' represents the positive relationship.

The correlation test was being conducted on the study data, the results as shown in Table 3 depicts that there is a significant positive relationship between technology readiness and IT competency.

Table 3. Correlations between Variables of the Study

\begin{tabular}{|c|c|c|}
\hline & ITC & TR \\
\hline ITC & 1 & \\
\hline TR & $.398^{\star *}$ & 1 \\
\hline
\end{tabular}

\subsection{Regression Analysis Test}

Regression analysis is adopted to test the effect of the studied independent variable technology readiness on the studied dependent variable. Table 4 below presents the result of a regression result test.

Table 4. The Coefficients (a) Value

\begin{tabular}{lllll}
\hline Construct & Standard Errors & Beta & t-value & Sig \\
\hline TR_IV1 & .057 & 0.398 & 6.935 & $.000^{* * *}$ \\
R Square & & & & 0.158 \\
F-Value & & & & 48.099 \\
Sig of F-value & & & 0.000 \\
\hline
\end{tabular}

Note: $\mathrm{P}<0.10^{*} ; \mathrm{P}<0.05^{* *} ; \mathrm{P}<0.01^{* * *} ;$ ITC $=$ IT Competency, TR=Technology Readiness.

Table 4 shows that technology readiness significantly and positively contributed to the prediction of IT competency at varied significant levels $(\beta=0.398, t=6.935, p<.01)$. Hence, hypothesis 1 is supported. Going by Cohen's (1988) R2 taxonomy, of value 0.02 is weak; R2 of value 0.13 is moderate while R2 of value 0.26 is substantial. The R2 of the 
current study, which stands at 0.158 , indicates that the independent variable (technology readiness) thus, $\mathrm{R} 2$ is substantial.

\section{CONCLUSION AND FUTURE RESEARCH}

The readiness of an IT user in embracing IT plays an important role in the acquisition or realisation of IT competencies. Technological readiness is the willingness and enthusiasm of an IT user in the application of IT in the actualisation of a task. Based on the previous literature, this study formulated hypothesis $\mathrm{H} 1$, which stipulates that there is a relationship between technology readiness and IT competencies among Iraqi accountants under the intensity of civil conflicts.

The result showed that there is a positive significant relationship between technological readiness and the IT competencies of Iraqi accountants. This result supports hypothesis $\mathrm{H} 1$, and it implies that the technology readiness regarding willingness, enthusiasm, and motivation of accountants using IT has an impact on their IT competencies. In other words, the higher the readiness of the accountants in making use of technology, the higher their competence in the use of IT. This result consistent with the previous finding of Lai (2008). Based on this finding, Iraqi accountants in the organisations can have a high level of IT competencies if they have the zeal and motivation to make use of technology. Therefore, organisations should promote and motivate accountants by embarking on programs and policies that can enhance their technological readiness. This will invariably lead to their competence in the application of IT.

In addition, since this study offers some empirical evidence regarding the technological readiness factors that predict IT competencies among accountants in Iraqi organisations in public sector, it could be worthwhile to replicate the findings across diverse industries, sectors and contexts, as this will enhance the generalizability of the current research findings.

Conclusively, other recommendations for future research include the adoption of a mixed method to provide more reliable conclusions on the issue of determinants of IT competencies, since the responses collected through quantitative method may not be adequate as some respondents may not like to answer questions appropriately. Also, selfreporting approach adopted in this research is not considered a significant limitation on the management-based research field (Spector, 2006), but investigating other employees' perspective regarding the predictors of IT competencies would constitute a viable research direction for the future studies. The reason is that examining other employees' perspectives on the predictors of IT competencies would expand the understanding and enrich the body of knowledge in the research field.

\section{REFERENCES}

ABC News Point, Top 10 Most Dangerous Countries in the World, http://www.abcnewspoint.com/top-10-most-dangerous-countries-in-the-world-2015.

Abduljalil, K. M., \& Zainuddin, Y. (2015). Integrating Technology Acceptance Model and Motivational Model towards Intention to Adopt Accounting Information System. International Journal of Management, Accounting and Economics, 2(5), 346-359.

Al-Busisi, H., \& Al-Khafaji, H. (2009). The quality of university scientific curriculum and techniques used in education to improve the quality of the education process reality and ambition. Paper 
presented at the Quality Assurance and Accreditation Our vision for the development of future, Al-Najaf.

Al-Dhahabi, G. A., \& Jacob, A. A. (2014). Strengthening the competence of the accounting profession according to the new Iraqi environment with the help of international experiences, The Arab Organization for Administrative Development.

Al-Fatlawi L. N., (2013). Accounting Environment and Indicators of Adaptation of Information Technology. First Annual General Arab Conference, The reality of the accounting profession among the challenges and ambition BAGHDAD - Iraq.

Al-Jaboree, A. H. (2012). Tasks of higher education in the curriculum development. Retrieved from: http: measurement.arabe.pro/t50-topic.

Azmi, M. F.(2017). New competency framework for accountants in the pipeline. Business News, The Star Online, http://www.thestar.com.my/

Bahador, K. M. K., \& Haider, A. (2012). Information Technology Skills and Competencies-A Case for Professional Accountants. In Business Information Systems Workshops (pp. 81-87). Springer Berlin Heidelberg.

Bain, C. E., Blankley, A. I., \& Smith, L. M. (2002). An examination of topical coverage for the first accounting information systems course. Journal of Information Systems, 16(2), 143-164.

Bassellier, G., Benbasat, I., \& Reich, B. H. (2003). The influence of business managers' IT competence in championing IT. Information Systems Research, 14(4), 317-336.

Berberoglu, G., \& Calikoglu, G. (1993). Factorial validity of the Turkish computer attitude scale. Studies in Educational Evaluation, 19(3), 257-263.

Board Supreme Audit of Iraq (BSA) (2014). The statistics of the e-auditing department.

Bobbitt, L. M., \& Dabholkar, P. A. (2001). Integrating attitudinal theories to understand and predict the use of technology-based self-service: the internet as an illustration. International Journal of Service Industry Management, 12(5), 423-450.

Borrero, J. D., Yousafzai, S. Y., Javed, U., \& Page, K. L. (2014). Expressive participation in Internet social movements: Testing the moderating effect of technology readiness and sex on student SNS use. Computers in Human Behavior, 30, 39-49.

Boyatzis, R. E. (1982). The competent manager: A model for effective performance. John Wiley \& Sons.

Caison, A. L., Bulman, D., Pai, S., \& Neville, D. (2008). Exploring the technology readiness of nursing and medical students at a Canadian University. Journal of Interprofessional Care, 22(3), 283-294.

Carroll, B., Levy, L., \& Richmond, D. (2008). Leadership as practice: Challenging the competency paradigm. Leadership, 4(4), 363-379.

Clardy, A. (2008). Human resource development and the resource-based model of core competencies: Methods for diagnosis and assessment. Human Resource Development Review, 7(4), 387-407.

Coe, M. J. (2006). Integrating IT audit into the AIS course. The Review Of Business Information System, 10(1), $105-119$.

Cohen, J. (1988). Statistical power analysis for the behavioural sciences (2nd ed.). Mahwah, NJ: Lawrence Erlbaum.

Colby, C. L., \& Albert, T. (2003). The role of culture in technology adoption in the US: Results of the African American and Latino technology readiness survey. Rockbridge News (The Periodical of Rockbridge Associates, Inc), 2.

CSO, (2013). Central Statistical Organization in Iraq. Indicators for using information and communication technology survey in manufacturing facilities, http://cosit.gov.iq/en/it-survey.

Curran, J. M., \& Meuter, M. L. (2005). Self-service technology adoption: comparing three technologies. Journal of Services Marketing, 19(2), 103-113.

Davis, F. D. (1989). Perceived usefulness, perceived ease of use, and user acceptance of information technology. MIS Quarterly, 13(3), 319-340.

Deppe, L. A., Sonderegger, E. O., Stice, J. D., Clark, D. C., \& Streuling, G. F. (1991). Emerging competencies for the practice of accountancy. Journal of Accounting Education, 9(2), 257290.

Dimitrios, N. K., Sakas, D. P., \& Vlachos, D. S. (2013). Analysis of strategic leadership models in information technology. Procedia-Social and Behavioral Sciences, 73, 268-275. 
Elliott, K. M., Meng, J., \& Hall, M. C. (2008). Technology readiness and the likelihood to use selfservice technology: Chinese vs. American consumers. Marketing Management Journal, 18(2), 20-31.

Fathema, N., Ross, M., \& Witte, M. M. (2014). Student Acceptance of University Web Portals: A Quantitative Study. International Journal of Web Portals (IJWP), 6(2), 42-58.

Fathema, N., Shannon, D., \& Ross, M. (2015). Expanding the Technology Acceptance Model (TAM) to examine Faculty use of Learning Management Systems (LMSs) in higher education institutions. MERLOT Journal of Online Learning and Teaching, 11(2), 210-232.

Erumban, A. A., \& De Jong, S. B. (2006). Cross-country differences in ICT adoption: A consequence of Culture? Journal of World Business, 41(4), 302-314.

Farby, S. (2004). Five technology consumers to watch. Rockbridge News, The Periodical of Rockbridge Associates, Inc, 2.

Garavan, T. N., \& McGuire, D. (2001). Competencies and workplace learning: some reflections on the rhetoric and the reality. Journal of Workplace Learning, 13(4), 144-164.

Gold, A., Malhotra, A. and Segars, A. (2001) Knowledge Management: An Organizational Capabilities Perspective. Journal of Management Information Systems, 18, 185-214.

Greenstein-Prosch, M., McKee, T. E., \& Quick, R. (2008). A comparison of the information technology knowledge of the United States and German auditors.

Hager, P., \& Beckett, D. (1995). Philosophical underpinnings of the integrated conception of competence. Educational Philosophy and Theory, 27(1), 1-24.

International Federation of Accountants Education Committee IFAC (2003). Information Technology for Professional Accountants, available at https://www.imanet.org/pdf/ITPA.

International Federation of Accountants IFAC (2006). International Educational Standard 7 (IES 7). Information Technology for Professional Accountants. International Federation of Accountants (IFAC) Available at: [online]. www.coe.uh.edu/insite/elec_pub/HTML1997/th_sian.htm.

International Federation of Accountants IFAC (2006a). Proposed International Educational Practice statement 2.1(IEPS 2.1). Information Technology for Professional Accountants. [Online]. http://www.nysscpa.orgPrint versions /cpaj /2004/ p34.htm

International Federation of Accountants IFAC IEPS 2 (2007).International Education Practice Statement 2: Information technology for professional accountants, International Accounting Education Standards Board, viewed 11 June 2008.

Ismail, N. A., \& Salim, a. B. (2005). Perceptions of accounting academicians toward the issue of Information technology integration into the accounting curriculum. Jurnal Penyelidikan Pendelikon, 7, 75-88.

Jaeger, P. T., \& Thompson, K. M. (2003). E-government around the world: Lessons, challenges, and future directions. Government information quarterly, 20(4), 389-394.

Jamil, R. (2015). What Is Wrong with Competency Research? Two Propositions. Asian Social Science, 11(26), 43.

Kaddouri, S., (2014)."International Accounting Standards and Their Impact on The Reform of The Accounting System in the Economy of Iraq "published research, the University of Ibn Rushd / Netherlands.

Kaye, G., R., Nicholson H., H., A. (1992) An educational framework for information technology in accounting and management education. Computers Education, 19, 105-112.

Khan, G. F., Moon, J., Zo, H., \& Rho, J. J. (2010). Civil conflict, digital divide, and e-government service adoption: A Conflict Theory Approach. World Academy of Science, Engineering and Technology, 66, 537-549.

Khan, G. F., Moon, J., Swar, B., Zo, H., \& Rho, J.J.(2012). E-government service use intentions in Afghanistan: Technology adoption and the digital divide in a war-torn country, Information Development, 28(4), 28 1-299.doi: 10.1 I77102666669 12438879

Kruger, J., \& Dunning, D. (1999). Unskilled and unaware of it: how difficulties in recognising one's incompetence lead to inflated self-assessments. Journal of personality and social psychology, 77(6), 1121.

Lai, M. L. (2008). Technology readiness, internet self-efficacy and computing experience of professional accounting students. Campus-Wide Information Systems, 25(1), 18-29. 
Lallo, N. Y., \& Selamat, M. H. (2013). Developing Standardized Accounting Information System (AIS) Course for Iraqi Higher Education: A Conceptual Framework. Asian Journal of Business and Accounting, 6(1).

Lee, S., \& Fang, X. (2008). Perception gaps about skills requirement for enter-level IS professionals between recruiters and students: An exploratory study. Information Resources Management Journal, 21(3), 39-62.

Liljander, V., Gillberg, F., Gummerus, J., \& Van Riel, A. (2006). Technology readiness and the evaluation and adoption of self-service technologies. Journal of Retailing and Consumer Services, 13(3), 177-191.

Lin, C. H., Shih, H. Y., \& Sher, P. J. (2007). Integrating technology readiness into technology acceptance: The TRAM model. Psychology \& Marketing, 24(7), 641-657.

Loyd, B.H. \& Gressard, C. (1984). Reliability and factorial validity of computer attitude scale. Educational and Psychological Measurement, 44, 501-505

Lu, J., Wang, L., \& Hayes, L. A. (2012). How do technology readiness, platform functionality and trust influence C2C user satisfaction?. Journal of Electronic Commerce Research, 13(1), 50.

Maldonado, U. P. T., Khan, G. F., Moon, J., \& Rho, J . J . (2011). E-learning motivation and educational portal acceptance in developing countries. Online Information Review, 35(1), 6685.

Massey, A. P., Khatri, V., \& Montoya-Weiss, M. M. (2007). Usability of online services: The role of technology readiness and context. Decision Sciences, 38(2), 277-308.

Meuter, M. L., Ostrom, A. L., Bitner, M. J., \& Roundtree, R. (2003). The influence of technology anxiety on consumer use and experiences with self-service technologies. Journal of Business Research, 56(11), 899-906.

Milus, S. (2004). The Institutions need for comprehensive auditing strategies. Information Systems Control Journal, 6, 1-6.

Ministry of Industry and Minerals (MIM), (2013), Report of IT competency among accountants in Iraqi organisations.

Mithas, S., Ramasubbu, N., \& Sambamurthy, V. (2011). How information management capability influences firm performance. MIS Quarterly, 35(1), 237.

Mohamed, E. K., \& Lashine, S. H. (2003). Accounting knowledge and skills and the challenges of a global business environment. Managerial Finance, 29(7), 3-16.

Nance, W. D., \& Straub, D. W. (1996). An investigation of task/technology fit and information technology choices in knowledge work. Journal of Information Technology Management, 7, 114.

Nunnally, J.C. (1978) Psychometric theory. 2nd Edition, McGraw-Hill, New York.

Pallant, J. (2011). SPSS survival manual: A step-by-step guide to data analysis using SPPS for the window (4th ed.). England: McGraw Hill Open University Press.

Parasuraman, A. (2000). Technology Readiness Index (TRI) a multiple-item scale to measure readiness to embrace new technologies. Journal of service research, 2(4), 307-320.

Parasuraman, A., \& Colby, C. L. (2001). Techno-Ready Marketing: How and WhyYour Customers Adopt Technology. New York: Free Press.

Parasuraman, A., \& Colby, C. L. (2015). An updated and streamlined technology readiness index: TRI 2.0. Journal of service research, 18(1), 59-74.

Pérez-López, S., \& Junquera, B. (2013). The relation between IT competency and knowledge management processes and its mediators. Tourism \& Management Studies, 9(1), 109-115.

Perry, S. (1990). Ideas for improving the transfer of learning. Adult Learning, 1 (7), 19-23.

Prahalad, C.K. \& Hamel, G. (1990). The Core Competences of the Corporation. Harvard Business Review, May - June.

Rom, A., \& Rohde, C. (2007). Management accounting and integrated information systems: A literature review. International Journal of Accounting Information Systems, 8(1), 40-68.

Sekaran, U. (2000). The research method for business: a skill-building approach. New York: Johnwileg\& Sons, Inc.

Sekaran, U. (2003). Research Method for Business, a Skill Building Approach. $4^{\text {th }}$ ed., New Delhi: John Wiley \& Sons.

Singh, S. (2006). Cultural differences in, and influences on, consumers' propensity to adopt innovations. International Marketing Review, 23(2), 173-191. 
Spector, P. E. (2006). Method variance in organisational research: truth or urban legend?. Organizational Research Methods, 9(2), 221-232.

Stone, D. N., Arunachalam, V., \& Chandler, J. S. (1996). Cross-cultural comparisons: an empirical investigation of knowledge, skill, self-efficacy and computer anxiety in accounting education. Issues in Accounting Education, 11(2), 345.

Summak, M. S., Bağlıbel, M., \& Samancıoğlu, M. (2010). Technology readiness of primary school teachers: A case study in Turkey. Procedia-Social and Behavioral Sciences, 2(2), 2671-2675.

Tabachnick, B. G., \& Fidell, L. S. (2007). Multivariate analysis of variance and covariance. Using multivariate statistics, 3, 402-407.

Tam, T. C. W. (2011). The relevant information technology knowledge and skills for accounting graduates in New Zealand.

Tippins, M. J., \& Sohi, R. S. (2003). IT competency and firm performance: is organisational learning a missing link?. Strategic management journal, 24(8), 745-761.

Tsikriktsis, Nikos (2004). A Technology Readiness-Based Taxonomy of Customers: A Replication and Extension. Journal of Service Research, 7(1), 42-52

United Nations (UN). (2014). Information and communication technology development indices. Paper presented at the United Nations Conference on Trade and development New York and Geneva.

Victorino, L., Karniouchina, E., \& Verma, R. (2009). Exploring the use of the abbreviated technology readiness index for hotel customer segmentation. Cornell Hospitality Quarterly, 50(3), 342359.

Walker, R. H., Craig-Lees, M., Hecker, R., \& Francis, H. (2002). Technology-enabled service delivery: An investigation of reasons affecting customer adoption and rejection. International Journal of Service Industry Management, 13(1), 91-106.

Wallace, A. R. (1999). An exploratory study of the factors influencing the construction of computer self-efficacy. Charles Sturt University.

Wang, H. I., \& Yang, H. L. (2005). The role of personality traits in the UTAUT model under online stocking. Contemporary Management Research, 1(1), 69-82.

Wessel, P., J.(2008) The Identification and Discussion of Strategies for Implementing an IT Skills Framework in the Education of Professional Accountants. South African Journal of Accounting Research, 22(1), 147-181. 